\title{
Stereotyping of Americans in Modern International Political Jokes and Anecdotes: A New Reality or an Old Form in New Clothes?
}

\author{
Oksana Romanovna Zhernovaya ${ }^{1}$ \\ ${ }^{1}$ Lobachevsky State University of Nizhni Novgorod-National Research University, Nizhny Novgorod, Russia \\ Correspondence: Oksana Romanovna Zhernovaya, Lobachevsky State University of Nizhni Novgorod-National \\ Research University, Nizhny Novgorod, Russia.
}

Received: July 30, 2014 Accepted: September 30, 2014 Online Published: December 30, 2014

doi:10.5539/ass.v11n3p267

URL: http://dx.doi.org/10.5539/ass.v11n3p267

\begin{abstract}
The paper deals with one of the topical issues of modern political discourse - "stereotypes". It addresses the issue of ethnic and cultural stereotypes of Americans and the changes of these stereotypes due to economic and socio-political events which have taken place in the world in the last few decades. It refers to the problem of Russian reading, understanding and interpreting American stereotypes in comparison with other cultures and nationalities. As an illustration the operating experience of the phenomenon of "stereotype" in jokes and political jokes, the perception of the phenomenon of Americans through the prism of anecdotes, the transformation of this phenomenon in the past few decades.
\end{abstract}

Keywords: stereotyping, political jokes, ethnic identity, national character, interethnic relations

\section{Introduction}

It's known that stereotypes are generalizations, or assumptions, that people make about the characteristics of all members of a group, based on an image (often wrong) about what people in that group are like. They are caused by intercultural or interethnic contacts, when the most typical characteristics of this or that national group of culture are easily identified (Ovcharov, 2008). It is a social and cultural sphere where the main stereotypes, accepted by a society, are formed in. The word "stereotype" is based on Greek origins meaning "firm, tough, or print, track"; it appeared in the French language (in typographic practice) and found its habitual semantic features of a repetitive but reduced way of reality, containing estimating orienteers (Romashko, 2009). The word stereotype was introduced into science in the European context by American journalist and political scientist U. Lippman as a social and cultural as well ideological notion in 1922 and is interpreted as "a cognitive image" (Thurman \& Efimova, 2014).

"Stereotype" - "fixed mental impression", "a fixed set of ideas about what a particular type of person is like, which is (wrongly) believed to be true in all cases" (The Concise Oxford Dictionary).

Stereotypes have their formal linguistic, mental and behavioral parameters and, being a basic component of a certain society's linguistic worldview, reflect specific for this society interpretation of visual environment (Berezovich, 2009).

In linguistic terms, stereotypes can be perceived as "stable, i.e. repetitive, and not appearing by accident combinations, fixed in collective memory on the level of lexemes" (Bartminskiy, 2009).

The most traditional stereotypes are the ethnic and cultural ones, shared not only within one culture but even broader, the opinions about the typical images of the representatives of different nationalities. S. M. Lipset points out that it's impossible to understand a country without seeing how it varies from others. "Those who know only one country know no country" (Huntington, 2008).

Under an ethnic stereotype, following E. Bartminskiy and E. Berezovich, we understand "a stable complex of naive ideas about some people, nation, reflecting peculiarities of national "xenophobia".

Ethnic and cultural stereotypes are perceived as examples to correspond to (Avralev \& Efimova, 2013). That's why stereotyping ideas about the national character peculiarities actually have an influence on people, stimulating them to form those traits of character reflected in a stereotype (Panin, 2012). 
Thus, the paper is focused on the analysis of the formation of national stereotypes of Americans in the contemporary context of social, political, economic, and cultural landscape.

\section{Materials and Methods}

The principle method of analysis used in the article is an all-round comparative analysis based on a systems approach. The issue of stereotypes formation is studied in its interrelation with economic, political and social changes that have taken place in the world for the last couple of decades. In our research work we used analytical articles and research works of outstanding American, European and Russian scholars and politicians.

Ethnic and cultural stereotypes are seen as an important factor of interethnic relations. The atmosphere, in which there are developed human ties between representatives of different nationalities, between peoples and states, depends on them. As Samuel Huntington writes: "When stereotypes appear, opponents are demonized, and "others" become enemies" (Huntington, 2008). It's particularly acute nowadays, when a lot of people react sharply and negatively to the slightest hint, touching somehow their national identity.

For example, some studies of stereotypes revealed that Americans are generally considered to be generous, friendly and tolerant, but also arrogant, impatient and domineering.

Stereotypes, in which ethnic and national prejudices are reflected, can be expressed in language, for example, in terms of ethnic nicknames. A great number of ethnic nicknames are fixed in the American version of the English language and can be explained by a variety of the US national structure. The basis of stereotypes, distinguished in ethnic nicknames, may form associations, for example, with the skin color (brown skin, darky, Obamian for Afro-American), articles of clothing (a blanket for Indian), cultural peculiarities (coca-cola drinker and hamburger-eater - American) (Novak, 2010).

Speaking about ethnic and cultural stereotypes, it's necessary to highlight the fact that while forming these stereotypes, all mechanisms of stereotyping are revealed most brightly: in spite of the opportunity of empiric cognition of the object (foreign nation), a value paradigm, defined as "we-they", towards it is so strong that it subjectifies an image to the limit and gives maximum possible divergences from rational knowledge (it's known, for example, that a foreigner can be compared to an animal or devil). Therefore, axiologicality of ethnic stereotypes, their belonging to the most ancient world-view basis of culture provides them with a noticeable place in the system of language as well as in folk discourses.

The reflection of national traits of character and behavior of people of any nation in language is very important and a joke or anecdote is seen to be some kind of a cultural project, including not only a system of particular values, norms and principles which exist in any culture, but it is also a way of self-realization of culture, its self-identification. Reading jokes about representatives of different nationalities helps people of various cultures and ethnicities to understand each other better and build intercultural bridges in international communication.

An anecdote is known to fix public life, everyday problems and events very vividly in its short plot, so it's a reaction to a situation, and sometimes it predetermines it. According to M. Novak, "an anecdote is some sort of a cultural project, it's not only a system of some values, regulations, existing in any culture, but also an algorithm, a deep program, which can determine the future of national culture, the ways of cultural self-realization, its self-identification" (Novak, 2010).

In the interview of the "Russian newspaper" the Doctor of Philology, the specialist in folk semiotics, S. Nekludov, outlines that an anecdote is "a very large and multithematic genre. It has neither ethnically forbidden nor religiously forbidden topics. On the $11^{\text {th }}$ of September a dangerous catastrophe happens in America and in two minutes there appears an anecdote about it on the Internet. In this sense, it's a completely cynical genre" (Novoselova, 2010).

Regarding ethnic anecdotes, it's necessary to admit that they are completely based on the stereotype ideas about this or that group of people. These stereotypes, according to S. Ter-Minasova, "not only reflect the most essential and typical traits of people's character, but form them in the eyes of other peoples as well as in their own eyes" (Ter-Minasova, 2008).

In ethnic anecdotes there is expressed an idea of "ethnic inequality" and people's attention is usually drawn to the negative images of "foreigners" as representatives of other races, ethnicities, religions and cultures. The main aim of ethnic anecdotes and jokes is mockery and insult of this or that ethnic group. That's why hyperbolization of ethnic stereotypes seems to be the most widely spread (used) ways of stereotyping mechanisms. These or those anthropological, social, cultural and other distinctive features of ethnicity-victim are assessed as disadvantages and described in jokes and anecdotes in a redundant manner. 
Ethnic anecdotes can be of two types - stories about representatives of one ethnicity and stories, containing comparison of representatives of different ethnic groups. The latter is characterized by marking representatives of other ethnic groups as cunning people or fools. Ethnic jokes are not a fixation of a negative society reaction to any alien element, but, on the contrary, an indication of recognizing this social group by this or that distinguishing feature.

\section{Results}

The most popular source of stereotyping ideas about national characters are so called international jokes, i.e. anecdotes, formed on some pattern plot: "representatives of different nationalities, find themselves in the same situation, react differently to it, corresponding to those traits of their national characters, which are attached to them in the homeland where the joke was formed" (Ter-Minasova, 2008).

A specific characteristic of international jokes is intentional exaggeration of positive characteristics of representatives of your own ethnicity and mocking of peculiarities of behavior, typical of other ethnicities. These peculiarities are subjectively perceived as abnormal, and as a result, funny and silly. It is on the basis of these anecdotes that a famous British sociologist C. Davis formulates his Theory of Ethnic Humor and exposes it in the article entitled "Ethnic Jokes, Moral Values and Social Boundaries". Paying attention to positive and negative aspects, reflected in traditional anecdotes of the Americans not only about other communities and nationalities, but also about themselves, C. Davis exposes the most common and usual contrasting as "silly-clever". Describing this contrast, C. Davis also admits that "ethnic jokes and anecdotes are surrounded by such notions as "stupidity", canniness, sexual behavior" and the traits pointed earlier become apparent in different nationalities while doing most usual banal things - while working, eating, or, for example, during warfare. "Specific peculiarity of American interethnic anecdotes is intending exaggeration of positive characteristics of representatives of their own ethnicity and mocking of peculiarities of behavior, typical of other ethnicities". "The heroes of anecdotes are of a precedent-related character, i.e. they are of a sort of mythologized ethnic heroes, who have in mass mind specific images, stereotypes and comic standards of behavior which are adequately perceived only by representatives of the nation creating an anecdote" (Davies, 2009).

\section{Discussion}

The limit of a number of characters in a joke is explained by an obligatory demand for awareness of characters and economy of linguistic means in order to create a comic effect. If 20 years ago collective ethnic names (for example, "a Frenchman", "an Englishman" or "an American") were widely used in anecdotes, today they are more often replaced with proper names, names of governmental officials - presidents, prime-ministers and so on.

For example, because of the fact that France was against the bombardment of Iraq in 2003, motivating this by the absence of proof that Iraq possessed weapons of mass destruction, this decision of the French government immediately affected the relations between France and the USA. A traditional combination of heroes in American ethnic jokes about the French is the following: a Frenchman is against an Englishman and an American, and if an Englishman is ironically spoken about, a Frenchman is angrily mocked at:

G. Bush, J. Chirac and T. Blair all go hunting. At the end of the night, they are cleaning their game and having a drink when Tony Blair stands and throws a bottle of whiskey in the air and yells "For Queen and Britain". He then pulls out a pistol and shoots the bottle out of the air. Chirac stands and throws a bottle of champagne in the air screaming, "Vive la France". He, too, pulls his pistol and shoots the bottle. George, not to be out done throws a can of beer in the air and pulls out his pistol. Then he shoots Chirac and yells "It doesn't get any better than this" (Derbeneva, 2012).

Probably, neither country in the world has so many stereotypes as America nor the Americans have. Each national trait of the Americans, positive or negative, cultural or political peculiarities of the country is reflected in jokes and anecdotes.

When Ralph Ellison said that "the joke is at the center of the American identity", he also meant that "identity is not a fixed principle, established once and for all, but a fluid masquerade, an ironic display of masks and styles, gestures and titles, which accrue around a space as come to be known a the self' (Ellison, 2003).

So, one of the most popular stereotypes about America is the conviction that the Americans are not interested in other countries, that the Americans are rather provincial people and a lot of them have never been abroad. "Even the majority of American Congressmen have never got a passport for going abroad, that's why they have a rather provincial view on the world along with the global meaning of America.

There is a "golden" rule in American politics - all politics is local, not even federal. The majority of news and what is of interests to the Americans is something that happens in their neighborhood: a school district, police 
district, and town. In this sense America is very self-oriented though it exerts external influence all over the world" (Horosho li zhit v Amerike? Uznay u Nikolaya Zlobina, 2012).

At the same time it's vital to understand that the USA pursues, first and foremost, its own national interests on the global arena and if any state decides to change the current rules of the game set by Americans in the world, it risks becoming an adversary of the US or even a rouge state.

The following ethnic anecdote visually demonstrates this stereotype:

Recently a worldwide survey was conducted by the U.N. The question asked was: "Would you please give your opinion about the food shortage in the rest of the world?" The survey was a huge failure. In Africa they didn't know what "food" meant. In Western Europe they didn't know what "shortage" meant. In Eastern Europe they didn't know what "opinion" meant. In South America they didn't know what "please" meant. And in the USA they didn't know what "the rest of the world" meant (Barskiy, 2009).

The Americans don't like travelling; don't learn foreign languages and other cultures. This stereotype is reflected, for example, in the following joke:

"What do you call someone who speaks three languages? "Multilingual". What do you call someone who speaks two languages? "Bilingual". What do you call someone who speaks one language? "An American" (USA jokes, 2012).

Outside their country, particularly among the Russians, the Americans have a reputation of a rather silly nation, and of course, this conviction is a source of a large amount of jokes in which lack of education of the Americans is criticized, and acomic effect is created on surprise and brevity of a reply:

1. "A Frenchman in Paris asks one tourist:

- Do you want to hear one funny story about stupid Americans?

- I'm American.

- No problems, I can tell this story twice, if you don't understand".

2. "What do you call a person who professionally generates maps of the world? "A cartographer". What do you call a person who studies the global distribution of natural resources? "A geographer". What do you call a person who is ignorant of global geography? "An American".

3. What is the difference between an American and a potato? - A potato is at least cultivated.

4. What do you call an educated person in America? - A tourist (Zalevskiy, 2011).

In spite of the fact that ignorance of the Americans in these jokes is clearly exaggerated, we can't say that they are completely based on a false stereotype. The American educational system is very specialized, directed at market where they need an advanced specialist, but not a person who can talk on any subject. And in this sense there is an impression that the Americans are stupid. Of course, they aren't stupid; they are educated differently, being market-oriented, and today's market requires quality but not quantity of knowledge.

Here is an interesting fact: in 2011 a journal "Newsweek" asked a million of the Americans chosen at random several questions, which are usually answered by immigrants who take the American citizenship test. Almost three quarters couldn't say why there was the Cold War, and $44 \%$ couldn't give a definition of The Bill of rights, which is an inalienable part of the constitution of the country (Borusyak, 2008).

Due to the fact that the process of changing stereotypes is very slow and hard, they tend to change only when reality, which stereotypes reflect, changes. And all these changes refer primarily to the emotional component of a stereotype. The ethnic and cultural stereotype is able to change and evolutionize depending on changing cultural, political and economic factors of a society. The positive aspect of the ethnic and cultural stereotype is its role in the formation of the world of nations.

According to former Russian Prime Minister E. Primakov changes in the US politics are now connected with the fact, that, while recognizing the factor of a multipolar world structure, Americans still see themselves in this system as the only superpower state. These judgments are based on the existing power of armed forces, economy, and political influence in the world (Political jokes, 2012). A political image of America in Russia today is a state, aimed at getting world supremacy, using aggressive military means and playing a role of "the world policeman". It seems that the entire world needs US help, and any military conflict requires its military intervention. Lots of political jokes about America in Russia are connected with these stereotypes. As one American politician said: "We will defend the citizens of the city not depending on whether the city citizens want to be defended or not. We will defend them in any case. We think it is right". The Americans consider it to 
be right for one simple reason. Although we are stupid, not well educated, our political system works and there are a lot of countries around us where nothing works (Novoselova, 2010).

For example:

1. Haven't you understood that American democracy is the best? Not yet?! So, we are flying to you!!!

2. The USA is the world sanitary man, it attacks weak and ill countries.

3. If Columbus hadn't discovered America, Iraq would have had fewer problems. Not only Iraq (Political jokes, 2012).

In these jokes the means of the US foreign policy are mocked at, i.e. military intervention and achievement of their own interests under the auspices of the spread of democracy, aspiration of the Americans for hegemony.

The fact that since the beginning of the 21 st century Russia has managed to improve its domestic conditions, consolidated and strengthened its power, improved its economy and exerted its international clout on the global stage, it can't but irritate the USA, which still strives for a unipolar world without any Russia's position in it.

According to Foreign minister S. Lavrov the "policy of ultimatums, the philosophy of superiority and domination" run counter to the needs of the 21 st century, including the formation of a "polycentric and democratic world order". (Lavrov, 2014)

It should be stressed that the creation of new dividing lines is unacceptable in the world no one has a monopoly on the truth and no one can customize global and regional processes to suit their needs.

Thus, both US foreign policy characterized by double standards and the essence of humor are based on revealing contradictions, an absurd situation, because such jokes reveal ambivalence of any political situation or phenomenon.

It's well-known that the style of any country's foreign policy depends on political leaders (Avralev \& Efimova, 2014). In such political jokes not the stupidity of the Americans as a nation but the actions of their military and political leaders are frequently mocked at. As a result, one more stereotype about the Americans in Russia is that they don't like the government, neither theirs', not anyone else's. And they show indulgence for politicians. During the last presidential campaign in the USA there appeared different jokes, such as:

What's the difference between Democrats and Republicans? Democrats remind us that life is unfair, and Republicans make sure it is (Davies, 2009).

Lack of education of some political leaders is shown, for example, in the following jokes:

1. "George W. Bush dies and goes to heaven. At the Pearly Gates, St Peter tells him: "You look like Bush, but can you prove who you really are? Einstein and Picasso both managed to prove their identity". George W. Bush looks bewildered and says: "Who are Einstein and Picasso?" St Peter sighs and says: "Come on in, George".

2. J. Bush found himself in the Paradise. He was brought to the court in front of the God. Being half-educated he can't recall how to address correctly to the God: "God? Jesus?". - "Allah", - God severely gave a hint.

3. It's been reported that British Prime Minister Tony Blair is going to be stepping down next summer. After hearing about it, President Bush said, "Damn, he's the only foreign guy who speaks American" (Political jokes, 2012).

Humor reveals ambivalence of any political situation. When a man experiences a sense of dissatisfaction with political affairs, humor helps to release aggression and strain, feel supremacy over politicians or political elite. J. Orwell said: "Every joke is like a tiny revolution".

Hillary Clinton reports to Barack Obama: "All sanctions on Iraq have been lifted. And there are three pieces of news to be reported - good, bad and very bad. Good news is that the Iraqi administration has formed pro-American security forces and bought US weaponry worth 1 billon \$. Bad news is that the supplier of all weaponry is Russia and very bad news is that it will be transferred through North Korea, Sudan, Syria, Afghanistan and Iran" (Novak, 2010).

In the light of the current Ukranian crisis and Russia's annexation of the Crimea when the USA and the West accused Russia of supporting the opposition in the southeastern part of Ukrain and the violation of territorial integrity of Ukraine, there have immediately appeared the new jokes on the Internet, which illustrate the absurdity of the US-led Western block.

Angella Merkel calls President Obama: "I have 3pieces of news to be reported on the Ukranians. We made Russians return the Crimea to Ukraine. 
Obama: "Cool of you!"

Merkel: "But Ukraine has become part of Russia".

Obama: "Are you pulling my leg? And what about Maidan?"

Merkel after some pause: "And Maidan is moving to Washington!"

\section{Conclusion}

To sum up, political humor plays a number of very important functions - It reflects reality, stores cultural heritage and is expressed in stereotypes that reflect the key issues of public consciousness. It helps to form national identity and serves as an indicator of existence of such ethnic identities. It contributes to easing tensions while creating some kind of distance between a man and a situation, thus smoothing interpersonal and intergroup differences and conflicts. Political humor helps to build political bridges and cements political reality, creating imaginary utopia of global equality between elite and the public, strong and weak states. It creates political socialization.

In the last two decades the situation with stereotyping of Americans in Russia has changed from neutral or negative to much more aggressive. It is caused by the fact that process of formation of national stereotypes of Americans is based on the conception that a political image of the USA is, first and foremost connected, with the idea that America is superpower which imposes its style of democratic development on other states and in Russian political jokes America is seen as "a scapegoat" in many world problems.

\section{References}

Avralev, N., \& Efimova, I. (2013). The Role of the International University Network Organizations in the Innovative Development of Russia. Middle-East Journal of Scientific Research, 14(10), 1277-1291.

Avralev, N., \& Efimova, I. (2014). Global university rankings as indicators of the implementation of the integration process and competitive tool in the context of globalization of higher education. Life Sci J, $11(10), 648-652$.

Barskiy, L. (2009). Anatomy of English humor (p. 153). Moscow, Izd-vo Krasand.

Bartminskiy, E. (2009). Basic stereotypes and profiling (based on the Polish language). Conference "Stereotypes in language, communication and culture" (pp. 11-21). Moscow.

Berezovich, E. L. (2009). Ethnic stereotypes in different cultural codes. Conference "Stereotypes in language, communication and culture" (pp. 22-31). Moscow.

Borusyak, L. (2008). Such a fun victory. Retrieved February 29, 2012, from http://www.polit.ru/article/2008/09/ 22/anekdot.

Davies, C. (2009). Ethnic Jokes, Moral Values and Social Boundaries. The British Journal of Sociology, 33(3), 384-403.

Derbeneva, A. N. (2012). Ethnic jokes and the reasons for their lack of understanding of other cultures in translation. Retrieved February 27, 2012, from http://www.translate-pro.ru/stati-o-perevode/etnicheskieanekdotyi-i-prichinyi-ih-neponimaniya-predstavitelyami-drugih-kultur.html.

Efimova, I. (2013). Rankings as Tools to Promote Global Education Market. World Applied Sciences Journal, 25(10), 1400-1404.

Ellison, R. (2003). The collected essays of Ralph Ellison (Ed.: J. F. Callahan, p. 108). New York: Modern Library.

Good to live in America? Discover with Nikolai Zlobin. Retrieved June 6, 2012, from http://www.chr.aif.ru/onlineconf/5768

Huntington, S. (2008). Who are we? Challenges to America's National Identity (p. 635). Moscow, AST.

Lavrov, S. (2014). Western bloc headed by Washington rejects UN principle that all states are equal.

Lavrov, S. (n. d.). Western bloc headed by Washington rejects UN principle that all states are equal. Retrieved October 3, 2014, from http://rt.com/news/191216-lavrov-us-rejects-principle/

Novak, M. I. (2010). Anecdote as a cultural-ideological project. World cultural and linguistic and political space: $A$ view through the centuries, 1, 358-363. Moscow: RGSU.

Novoselova, E. (2010). Who comes up with anecdote? Rossiyskaya gazeta, № 283. 
Ovcharov, A. (2008). The Russian tourist industry: Trends and risks. Social Sciences, 39(3), 4-15.

Panin, V. V. (2012). Ethnic stereotypes in English Languages and literatures (№ 22). Retrieved February 27, 2012, from http://www.frgf.utmn.ru/mag/22/47

Political jokes. Retrieved February 29, 2012, from http://www.jokesgallery.com/categories.php?category= CleanPolitical.

Primakov, E. (2012). Stereotypes are dangerous in politics. Retrieved February 29, 2012, from http://www.inosmi.ru/russia/20090202/247122.html.

Romashko, S. A. (2009). Stereotype to the linguistic and cultural archeology words and concepts (p. 598).

Ter-Minasova, S. G. (2008). War and Peace, languages and cultures (pp. 47-344). Moscow: Slovo.

Thurman, P. W., \& Efimova, I. (2014). Use of rankings to improve global competitiveness of Russian's higher education institutions and technology exports. Life Sci J, 11(11), 285-289.

USA jokes. Retrieved February 29, 2012, from http://www.lukaroski.com/jokes/usa.asp

Zalevskiy, T. (2011). Monstrous ignorance of Americans. Retrieved February 29, 2012, from http://www.rus.ruvr.ru/2011/12/11/62008851.htm

\section{Copyrights}

Copyright for this article is retained by the author(s), with first publication rights granted to the journal.

This is an open-access article distributed under the terms and conditions of the Creative Commons Attribution license (http://creativecommons.org/licenses/by/3.0/). 